Artikel

\title{
Analisis Performance Fuzzy Tsukamoto Dalam Klasifikasi Bantuan Kemiskinan
}

\section{Sri Redjeki ${ }^{1}$}

${ }^{1}$ STMIK AKAKOM, Teknik Informatika, Yogyakarta,Indonesia

\begin{tabular}{l}
\hline SUBMISSION TRACK \\
\hline Terima: 28 Agustus 2017 \\
Revisi Akhir: 10 September 2017 \\
Tersedia Online: 15 September 2017 \\
KEYWORD \\
\hline
\end{tabular}

Fuzzy Inference, Poverty, Tsukamoto

KORESPONDENSI

Phone: 081393108866

E-mail: dzeky@akakom.ac.id

\begin{abstract}
A B S T R A C T
The Central Bureau of Statistics (BPS) showed that the poverty rate in Indonesia in September 2014 still high at about 27.7 million people, or about 10.96\%. As a basis for policy countermeasures, understand the problem of poverty often demands the effort of defining, measuring, and identifying the root causes of poverty. This study wanted to use one of the methods that exist in fuzzy logic to classify beneficiaries of poverty that exist in Bantul. Fuzzy Inference System used in this study using Tsukamoto with 8 rule established by a group of poor criteria and types of poverty relief. There are three groups of criteria of poverty derived from 11 criteria of poverty in Bantul. While the types of assistance that are used are Raskin, BLT and KUR. The system is built using PHP. To see the performance Tsukamoto method in this study used 50 data poor people in Sub Districs Banguntapan. From the test results turned out to obtained an accuracy of 52\%, meaning that there were 26 correct data according to the original data. It is necessary to modify the rules and membership functions to improve system accuracy results
\end{abstract}

\section{PENDAHULUAN}

Data Biro Pusat Statistik (BPS) menunjukkan bahwa di Indonesia angka kemiskinan pada bulan September 2014 masih tinggi sekitar 27,7 juta orang atau sekitar 10,96\% (bps.go.id). Sebagai dasar untuk kebijakan pengentasannya, memahami masalah kemiskinan seringkali menuntut adanya upaya pendefinisian, pengukuran, dan pengidentifikasian akar-akar penyebab kemiskinan. Sebenarnya, berbagai kajian yang ditujukan untuk mengklasifikasi kemiskinan dan menganalisis penyebabnya telah banyak dilakukan. Namun upaya-upaya tersebut belum tuntas, karena kemiskinan bersifat multidimensi dan karena kemiskinan bersumber dari aneka kondisi.

Sri Harijati Hatmadji (2004) mengungkapkan, sesungguhnya dimensi kemiskinan yang memadai dan sesuai perkembangannya harus mencakup berbagai dimensi, tidak hanya berurusan dengan pemenuhan atau kesejahteraan materi semata (material well- being), namun juga terkait erat dengan kesejahteraan sosial (sosial wellbeing).

Hal ini sesuai dengan indikator kemiskinan menurut Badan Pusat Statistik (BPS) yang menyebutkan bahwa kemiskinan 
diukur berdasarkan kemampuan memenuhi kebutuhan dasar, yang artinya kemiskinan dipandang sebagai ketidakmampuan dari sisi ekonomi untuk memenuhi kebutuhan dasar makanan dan bukan makanan yang diukur dari sisi pengeluaran (Cahyat, 2004).

Pemerintah telah berupaya untuk mengurangi tingkat kemiskinan di setiap daerah. Hal ini ditunjukkan dengan adanya penurunan angka kemiskinan di setiap propinsi (BAPPENAS, 2012). Dengan mencanangkan berbagai program pengentasan kemiskinan, diantaranya dengan adanya program kluster 1 untuk program penanggulangan kemiskinan terpadu berbasis rumah tangga (jenis bantuan beras untuk rakyat miskin (Raskin), jaminan kesehatan masyarakat (Jamkesmas), bantuan langsung tunai (BLT), bantuan opersional sekolah (BOS), beasiswa miskin (BSM), program keluarga harapan (PKH), kluster 2 untuk program penanggulangan kemiskinan berbasis komunitas (jenis bantuan PNPM Mandiri di perkotaan dan perdesaan), kluster 3 program penanggulangan kemiskinan berbasis usaha mikro dan kecil (jenis bantuan Kredit Mikro, Kredit Usaha Rakyat/KUR) (TN2PK, 2011). Pendanaan penanggulangan kemiskinan selalu meningkat dari tahun ke tahun, namun demikian mekanisme penyaluran dana masih tersebar di berbagai departemen. Implikasinya adalah dalam pelaksanaan seringkali keterkaitan antar program penanggulangan kemiskinan baik dipusat mau daerah belum optimal (Royat, Sujana )

Khususnya program bantuan kluster 1 yang berbasis keluarga, Pemerintah memberikan bantuan sosial kepada keluarga rentan miskin guna mengurangi beban ekonomi keluarga akibat kenaikan harga BBM, dari dampak putus sekolah, mengkonsumsi makanan rendah gizi, dan menjual asset keluarga. Adapun pendistribusian bantuan diselenggarakan dengan memberikan bantuan kepada keluarga pemilik Kartu Perlindungan Sosial (KPS) (TN2PK, 2011).

Program penanggulangan kemiskinan yang menjadi harapan pemerintah yaitu berbasis usaha mikro dan kecil. Usaha mikro dan kecil merupakan basis ekonomi rakyat sehingga perlu adanya program Kredit Usaha Rakyat (KUR). Program ini merupakan implementasi dari Inpres No. 6 tahun 2007 tentang Percepatan Sektor Riil dan Pemberdayaan Usaha Mikro, Kecil dan Menengah. Disini kehadiran program KUR dimaksudkan untuk mempermudah akses UMKM kepada layanan kredit dari perbankan dengan adanya skema dana penjaminan yang disediakan oleh pemerintah melalui perusahaan penjamin. KUR selanjutnya ditetapkan sebagai salah satu program utama penanggulangan kemiskinan dalam Klaster 3 yakni pemberdayaan masyarakat miskin berbasiskan usaha untuk menghasilkan pendapatan rumah tangga (TNP2k, 2012).

Kendala belum maksimalnya program penanggulangan kemiskinan banyak diindikasikan kepada ketidaktepatan penyaluran jenis bantuan kemiskinan yang ada. Logika fuzzy merupakan salah satu komponen pembentuk soft computing yang sangat membantu dalam penyelesaian masalah yang mempunyai banyak kekaburan (fuzzy). Hal ini karena logika fuzzy mampu beradaptasi dengan perubahan-perubahan dan ketidakpastian yang menyertai permasalahan. Penelitian ini menggunakan salah satu metode fuzzy inference yang ada untuk dapat membantu memberikan rekomendasi bagi penerima bantuan kemiskinan yang ada di Kabupaten Bantul khususnya Kecamatan Banguntapan. 
Beberapa tulisan yang dijadikan referensi guna memperkuat pembahasan dan analisa dalam penelitian ini antara lain:

Penggunakan fuzzy Analytical Hierarchy Process (F-AHP) untuk menentukan penerima Surat Keterangan Tidak Mampu (SKTM) yang digunakan untuk menerima bantuan perawatan medis di kota Sukabumi. Penggunaan F-AHP digunakan untuk menentukan bobot penilaian terhadap kriteria yang digunakan, yaitu sejumlah 14 kriteria yang ditetapkan oleh Badan Pusat Statistik (BPS). Dengan menentukan peringkat bobot fuzzy, kandidat penerima SKTM ditentukan berdasarkan kriteria kepentingan relatif yang dihasilkan (Fiarni, dkk 2013). Sistem pendukung keputusan penentuan warga penerima Jamkesmas dengan metode Fuzzy Tsukamoto oleh Miftahus Sholihin (2013).

Sistem penentuan keluarga penerima KPS menggunakan Fuzzy Inference System metode Tsukamoto menggunakan 14 kriteria kemiskinan versi BPS. Sebagai keluaran sistem berupa skor rumah tangga, status rekomendasi bantuan, dan jumlah warga desa/kelurahan (sugianti,2016) .

Penentuan prioritas rumah tangga miskin menggunakan fuzzy tsukamoto. Penelitian ini membentuk peringkat rumah tangga miskin sehingga dapat diketahui urutan rumah tangga yang berhak untuk mendapatkan bantuan. Pemilihan kriteria yang digunakan dalam perhitungan didasarkan pada ketentuan BPS mengenai kriteria rumah tangga miskin. Dari hasil pengujian menggunakan Spearman Correlation, didapatkan nilai korelasi sebesar 0.7776, yang menunjukkan bahwa ada keterkaitan yang tinggi antara peringkat yang dihasilkan oleh sistem dengan peringkat hasil perhitungan BPS (Vivi Nur dkk, 2016).
Logika fuzzy adalah suatu cara yang tepat untuk memetakan suatu ruang input ke dalam suatu ruang output. Dasar logika fuzzy adalah teori himpunan fuzzy.

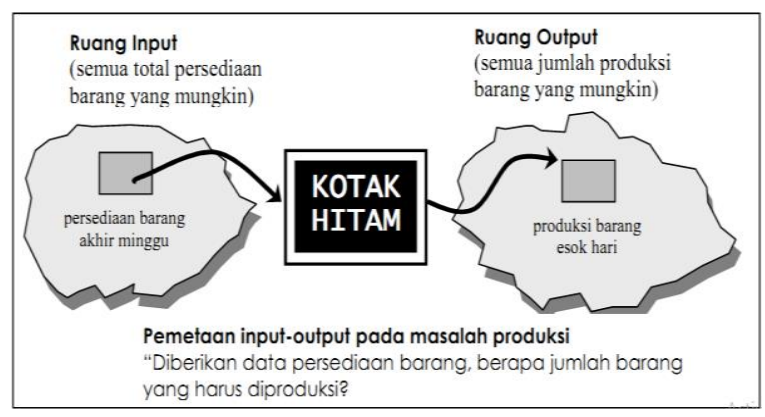

Gambar 1 Prose Logika Fuzzy

Pada teori himpunan fuzzy peranan derajat keanggotaan sebagai penentu keberadaan elemen dalam suatu himpunan sangatlah penting. Pada Gambar 1 logika fuzzy dapat dianggap sebagai kotak hitam yang berhuungan antara ruang input menuju ruang output [Kusumadewi, 2003]. Kotak hitam yang dimaksudkan adalah metode yang dapat digunakan untuk mengolah data input menjadi output dalam bentuk informasi yang baik.

Adapun beberapa alasan mengapa digunakannya logika fuzzy adalah:

1. Konsep logika fuzzy mudah dimengerti.

2. Penggunaan logika fuzzy yang fleksibel.

3. Logika fuzzy mampu memodelkan fungsifungsi nonlinear yang sangat kompleks.

4. Tidak perlu adanya proses pelatihan untuk memodelkan pengtahuan yang dimiliki oleh pakar.

5. Logika fuzzy didasari pada bahasa seharihari sehingga mudah dimengerti. Himpunan fuzzy disebut himpunan tegas (crisp), nilai keanggotaan suatu item $\mathrm{x}$ dalam suatu himpunan A yang dituliskan dengan $\mu[\mathrm{x}]$, dimana memiliki dua buah kemungkinan nilai yaitu:

\section{LOGIKA FUZZY}


1. Satu (1), yang memiliki arti bahwa suatu item menjadi anggota dalam suatu himpunan tertentu.

2. Nol (0), yang memiliki arti bahwa suatu item tidak menjadi anggota dalam suatu himpunan tertentu.

Himpunan fuzzy memiliki dua atribut yaitu:

1. Lingustik, merupakan penamaan grub yang mewakili suatu keadaan atau kondisi tertentu dengan menggunakan bahasa alami/seharihari. Contohnya : PENDEK, SEDANG, TINGGI

2. Numeris, merupakan sutau nilai angka yang menunjukkan ukuran dari suatu variabel.

Logika fuzzy secara umum memiliki tahapan pengerjaan sebagai berikut [Singhala, Shah, \& Patel, 2014]:

1. Menentukan variabel linguistik.

2. Membentuk fungsi keanggotaan.

3. Membentuk rule base.

4. Mengubah data crisp menjadi nilai fuzzy menggunakan fungsi keanggotaan.

5. Melakukan evaluasi rule pada rule base.

6. Menggabungkan hasil yang didapatkan pada setiap rule.

7. Mengubah output data menjadi nilai nonfuzzy.

\section{METODE TSUKAMOTO}

Sistem Inferensi Fuzzy merupakan suatu kerangka komputasi yang didasarkan pada teori himpunan fuzzy, aturan fuzzy berbentuk IF - THEN, dan penalaran fuzzy. Secara garis besar, diagram blok proses inferensi fuzzy terlihat pada gambar 2 . [Kusumadewi, 2003].

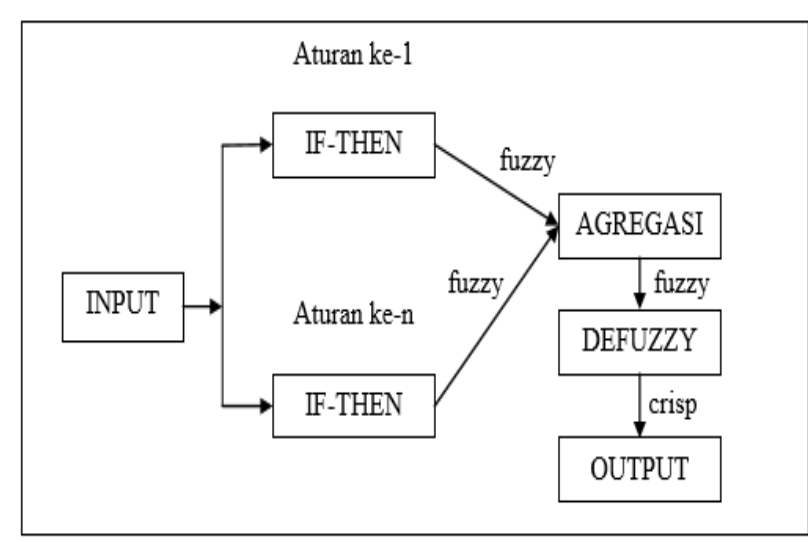

Gambar 2. Diagram Blok Fuzzy Tsukamoto

Sistem inferensi fuzzy menerima input crisp. Input ini kemudian dikirim ke basis pengetahuan yang berisi n aturan fuzzy dalam bentuk IF-THEN. Fire strength akan dicari pada setiap aturan. Apabila jumlah aturan lebih dari satu, maka akan dilakukan agregasi dari semua aturan. Selanjutnya, pada hasil agregasi akan dilakukan defuzzy untuk mendapatkan nilai crisp sebagai output sistem. Pada dasarnya, metode tsukamoto mengaplikasikan penalaran monoton pada setiap aturannya. Kalau pada penalaran monoton, sistem hanya memiliki satu aturan, pada metode tsukamoto, sistem terdiri atas beberapa aturan. Karena menggunakan konsep dasar penalaran monoton, pada metode tsukamoto, setiap konsekuen pada aturan yang berbentuk IF-THEN harus direpresentasikan dengan suatu himpunan fuzzy dengan fungsi keanggotaan yang monoton.

\section{METODE PENELITIAN}

\section{Kebutuhan Data}

Data yang digunakan pada penelitian ini merupakan data penerima bantuan keluarga miskin di Kecamatan Banguntapan yang merupakan salah satu Kecamatan yang ada di wilayah Kabupaten Bantul. Data penelitian primer ini diperoleh langsung dari SKPD BKKPPKB yang ada di Kabupaten 
Bantul. Kebutuhan data untuk pengembangan perangkat lunak ini yaitu data masyarakat miskin yang termasuk di dalamnya data variabel pendukung penerima bantuan. Data sampel tersebut didapat dari Pemerintah Kecamatan Banguntapan Bantul yang terdiri dari 60 data warga miskin. Penginputan data dilakukan oleh admin. Data masyarakat yang diperlukan antara lain :

1. Nomor kartu keluarga (KK)

2. Nama kepala keluarga

3. NIK kepala keluarga

4. Jenis Kelamin

5. Desa

6. Pedukuhan

7. RT

8. Bantuan yang diterima

Adapun variabel yang digunakan untuk perhitungan fuzzy tsukamoto terdiri dari 11 variabel (kriteria) yang digunakan di Kabupaten Bantul dengan rincian sebagai berikut :

1. Seluruh anggota keluarga tidak mampu makan minimal 2 kali dalam sehari (+1500 untuk 1 kali makan per jiwa) (poin : 12).

2. Sebagian besar anggota tidak memiliki pakaian yang pantas pakai (min 6 stel) (poin : 9).

3. Tempat tinggal/rumah berlantai tanah/ berdinding bambu/ beratap rumbia (poin: 9).

4. Jumlah penghasilan yang diterima seluruh anggota keluarga berusia 16 tahun keatas (termasuk KK) rata rata perbulan Rp.993.484,- ( poin : 35).

5. Bila anggota keluarga sakit tidak mampu berobat ke fasilitas kesehatan dasar (Puskesmas) ( poin : 6).

6. Keluarga tidak mampu menyekolahkan anak yang berumur 7-15 tahun(poin : 6).

7. Jumlah kekayaan milik keluarga (diluar tanah dan bangunan) $<$ Rp.2,5 juta(poin : $5)$.

8. Tanah dan bangunan yang ditempati bukan milik sendiri(poin : 6).

9. Tidak menggunakan air bersih untuk keperluan makan, minum, dan $\operatorname{MCK}($ poin : 4).
10. Tidak menggunakan akses listrik untuk kebutuhan rumah tangga(poin : 3 ).

11. Jumlah anggota jiwa dalam KK (termasuk kepala keluarga) 5 jiwa atau lebih (poin 5).

Dari 11 Variabel/kriteria yang ada dikelompokan menjadi 3 aspek yang terlihat pada tabel 1.

Tabel 1. Pengelompokkan Kriteria

\begin{tabular}{|c|c|c|}
\hline No & Kriteria & Aspek \\
\hline 1 & Pangan & \multirow{3}{*}{ Penentu } \\
\hline 2 & Sandang & \\
\hline 3 & Papan & \\
\hline 4 & Penghasilan & Penyebab \\
\hline 5 & Kesehatan & \multirow{7}{*}{ Pendukung } \\
\hline 6 & Pendidikan & \\
\hline 7 & $\begin{array}{l}\text { Kekayaan } \\
\text { (Rupiah) }\end{array}$ & \\
\hline 8 & $\begin{array}{l}\text { Kekayaan } \\
\text { Tanah }\end{array}$ & \\
\hline 9 & Air & \\
\hline 10 & Listrik & \\
\hline 11 & Jiwa & \\
\hline
\end{tabular}

Pengelompokkan kriteria menjadi aspek yang ada pada tabel 1 akan digunakan untuk pembuatan dasar Fuzzy Inferensi Tsukamoto.

\section{BLOK DIAGRAM SISTEM}

Gambar 3 menunjukkan blok diagram sistem analisis performance Fuzzy Tsukamoto dalam menentukan bantuan Kemiskinan di Kabupaten Bantul. 


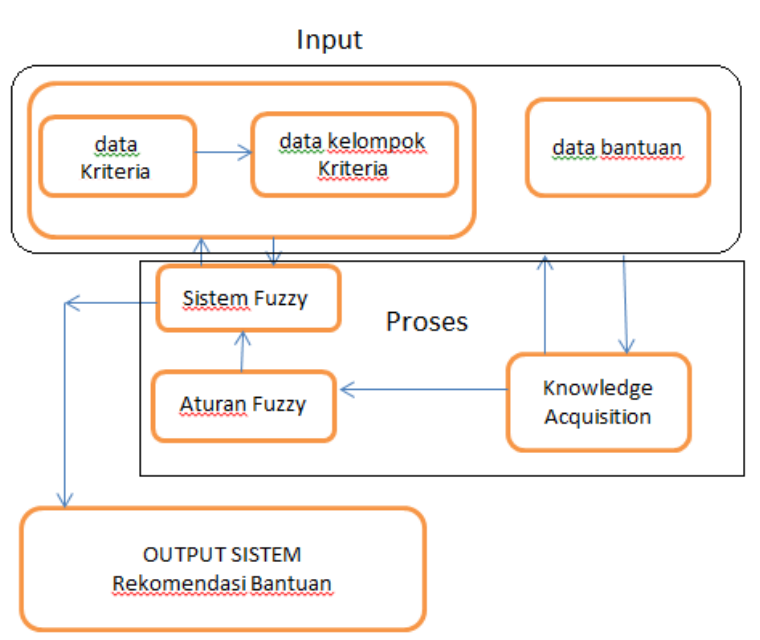

Gambar 3. Diagram Blok Sistem

Penjelasan gambar 3 sebagai berikut :

\section{Input Sistem}

Pada sistem ini menggunakan data warga miskin yang meliputi data kriteria kemiskinan sebanyak 11 kriteria. Masingmasing kriteria dikelompokkan kedalam 3 faktor kriteria yaitu faktor penentu, faktor penyebab dan faktor pendukung. Pengelompokkan ini bersumber pada buku petunjuk teknis Penyusunan dan Pengumpulan Data Statistik Daerah khusus Keluarga Miskin Kabupaten Bantul 2013. Selain data kriteria warga miskin juga di inputkan data bantuan yang pernah diterima oleh masing-masing warga miskin yang dijadikan sampel pada penelitian ini.

\section{Proses Sistem}

Pada tahapan proses ini terdapat 2 blok yaitu system fuzzy dan Basis aturan fuzzy. Fuzzy System berisi proses perhitungan fuzzy yang menghitung $\mu$ tiap kelompok kriteria yang ada. Basis aturan fuzzy berisi pengalaman yang dimiliki oleh pakar akan digunakan untuk membuat fuzzy rule base. Dalam hal ini pakar yang dimaksud adalah SKPD BKKPPKB. Pada fuzzy rule base akan terdapat pernyataan kondisi dan pada umunya akan direpresentasikan dengan menggunakan IF dan ELSE. Blok terakhir yang ada pada tahapan proses adalah Knowledge Acquisition. Knowledge Acquisition digunakan untuk akumulasi, transfer dan transformasi keahlian dari sumber pengetahuan pakar ke dalam program komputer. Dalam tahap ini knowledge engineer berusaha menyerap pengetahuan pakar (tenaga ahli pelaksana proyek) dan selanjutnya ditransfer ke dalam basis pengetahuan untuk menentukan lama pengerjaan pembangunan.

\section{Output Sistem}

Output sistem akan memberikan rekomendasi bantuan yang paling cocok bagi warga miskin di Kecamatan Banguntapan. Pada penelitian ini jenis bantuan dibagi menjadi 3 yaitu Raskin (beras bagi orang miskin), BLT (bantuan langsung tunai) dan KUR (kredit usaha rakyat)

\section{RANCANGAN FUZZY TSUKAMOTO}

Untuk menganalisis hasil sebuah system yang dibangun menggunakan fuzzy tsukamoto, tahapan yang harus dilakukan adalah mendesain fungsi tsukamoto dengan tepat dan melakukan simulasi perubahan rule yang ada. Desain fungsi tsukamoto meliputi :

1. Fungsi keanggotaan untuk 3 kelompok kriteria yaitu variabel penentu, variabel penyebab dan variabel pendukung.

2. Fungsi keanggotaan bantuan yang terdiri dari bantuan Raskin, BLT dan KUR.

3. Aturan fuzzy Tsukamoto yang dibuat dengan mengkombinasikan variabel bantuan dan juga variabel kelompok kriteria. Jumlah aturan yang di desain sebanyak 8 aturan.

Implikasi dan agregasi yang dibuat mengikuti aturan fuzzy tsukamoto sebanyak 8 implikasi dan agregasi.

\section{Fungsi Keanggotaan Kriteria Penentu}




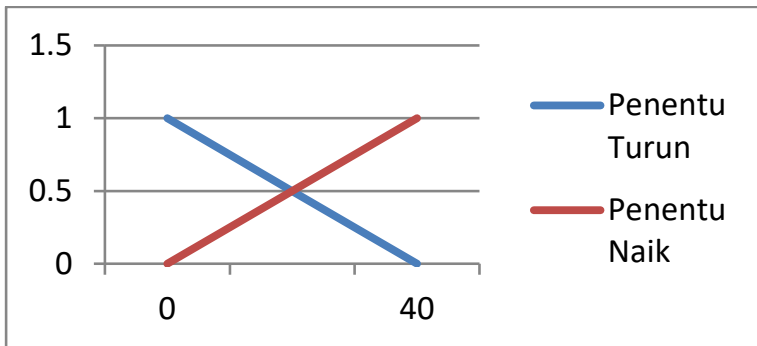

Gambar 4. Fungsi Keanggotaan Kriteria Penentu

Penentu_turun $(x)\left\{\begin{array}{rc}1 ; & x \leq 0 \\ \frac{40-x}{40} ; & 0<x<40 \\ 0 ; & x \geq 40\end{array}\right.$ Penentu_naik $(x)\left\{\begin{array}{rc}0 ; & x \leq 0 \\ \frac{x-0}{35} ; & 0<x<40 \\ 1 ; & x \geq 40\end{array}\right.$

2. Fungsi Keanggotaan Variabel Penyebab

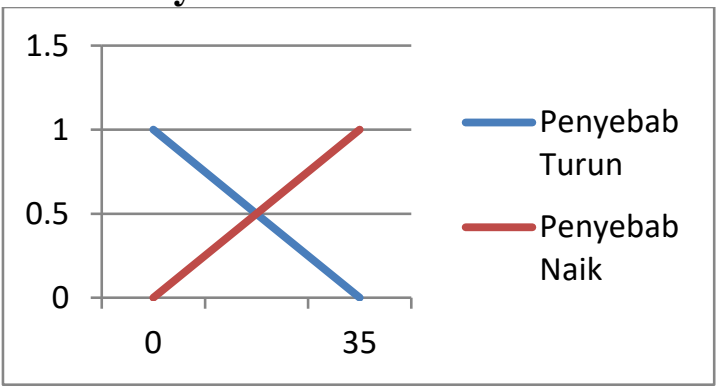

Gambar 5 Fungsi Keanggotaan Variabel Penyebab

Penyebab_turun $(x)\left\{\begin{array}{cc}1 ; & x \leq 0 \\ \frac{35-x}{35} ; & 0<x<35 .(3) \\ 0 ; & x \geq 35\end{array}\right.$

Penyebab_naik $(x)\left\{\begin{array}{cc}0 ; & x \leq 0 \\ \frac{x-0}{35} ; & 0<x<35 \\ 1 ; & x \geq 35\end{array}\right.$

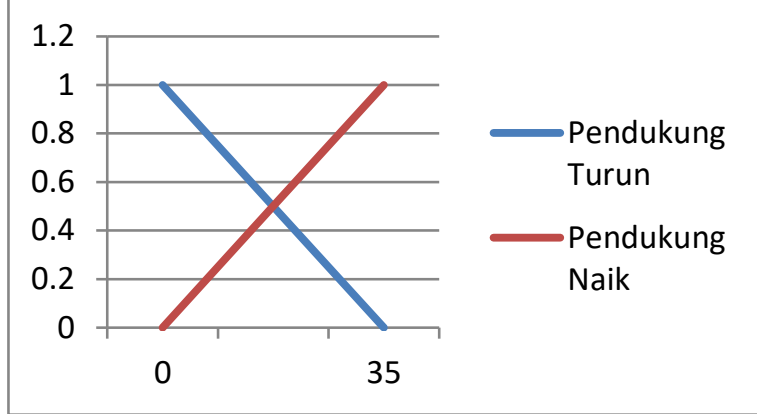

Gambar 6. Fungsi Keanggotaan Kriteria Pendukung

(1) Pendukung_turun $(x)\left\{\begin{array}{c}1 ; \quad x \leq 0 \\ \frac{35-x}{35} ; 0<x<35 \\ 0 ; \quad x \geq 35\end{array}\right.$

Pendukung_naik $(x)\left\{\begin{array}{cc}0 ; & x \leq 0 \\ \frac{x-0}{35} ; & 0<x<35 \\ 1 ; & x \geq 35\end{array}\right.$

\section{Fungsi Keanggotaan Jenis Bantuan}

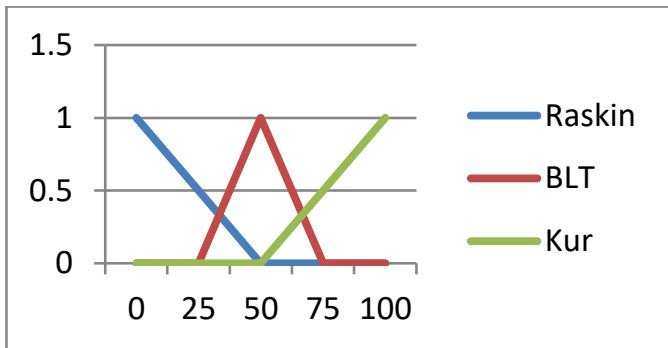

Gambar 7. Fungsi Keanggotaan Variabel bantuan

$$
\begin{gathered}
\operatorname{Raskin}(x)\left\{\begin{array}{c}
1 ; x \leq 0 \\
\frac{50-x}{50} ; 0<x<50 \\
0 ; x \geq 50
\end{array}\right. \\
\operatorname{BLT}(x)\left\{\begin{array}{c}
0 ; x \leq 25 \text { or } x \geq 75 \\
\frac{x-25}{25} ; 25<x<50 \\
\frac{75-x}{25} ; 50<x<75 \\
0 ; \quad x \leq 0
\end{array}\right. \\
\operatorname{Kur}(x)\left\{\begin{array}{cc}
\frac{x-0}{100} ; & 0<x<50 \\
1 ; & x \geq 50
\end{array}\right.
\end{gathered}
$$

\section{Rule (Aturan) Fuzzy Tsukamoto}

Aturan ini digunakan untuk mengklasifikasikan jenis bantuan yang diterima oleh warga miskin berdasarkan

\section{Fungsi Keanggotaan Kriteria Pendukung}


fungsi keanggotaan yang ada. Terdapat 8 aturan yang digunakan pada penelitian ini.

1. If Penentu Naik, Penyebab Naik, Pendukung Naik Then KUR

2. If Penentu Naik, Penyebab Naik, Pendukung Turun Then BLT

3. If Penentu Naik, Penyebab Turun, Pendukung Naik Then BLT

4. If Penentu Naik, Penyebab Turun, Pendukung Turun Then Raskin.

5. If Penentu Turun, Penyebab Naik, Pendukung Naik Then BLT

6. If Penentu Turun, Penyebab Naik, Pendukung Turun Then Raskin

7. If Penentu Turun, Penyebab Turun, Pendukung Naik Then Raskin.

8. If Penentu Turun, Penyebab Turun, Pendukung Turun Then Raskin

Dari 8 rule diatas akan di desain fungsi implikasi dan fungsi agregasi yang terlihat pada tabel 2 .

Tabel 2. Fungsi Implikasi dan Agregasi

\begin{tabular}{|c|c|c|}
\hline No & Fungsi Implikasi & Fungsi Agre \\
\hline 1 & $\begin{array}{l}\text { R1 = Min(Penentu } \\
\text { Naik, Penyebab Naik, } \\
\text { Pendukung Naik) }\end{array}$ & $\begin{array}{l}\mathrm{z} 1= \\
(\$ R 1 * 50)+50\end{array}$ \\
\hline 2 & $\begin{array}{l}\text { R2 = Min(Penentu } \\
\text { Naik, Penyebab Naik, } \\
\text { Pendukung Turun) }\end{array}$ & $\begin{array}{l}\mathrm{z} 2= \\
(\$ R 4 * 25)+25 \\
\$ \mathrm{z} 2=75- \\
(\$ R 3 * 25) ;\end{array}$ \\
\hline 3 & $\begin{array}{l}\text { R3 = Min(Penentu } \\
\text { Naik, Penyebab Turun, } \\
\text { Pendukung Naik) }\end{array}$ & $\begin{array}{l}\mathrm{z} 3= \\
(\$ R 4 * 25)+25 \\
\$ \mathrm{z} 3=75- \\
(\$ R 3 * 25)\end{array}$ \\
\hline 4 & $\begin{array}{l}\text { R4 = Min(Penentu } \\
\text { Naik, Penyebab Turun, } \\
\text { Pendukung Turun) }\end{array}$ & $\begin{array}{l}\mathrm{z} 4=50- \\
(\$ \mathrm{R} 8 * 50)\end{array}$ \\
\hline 5 & $\begin{array}{l}\text { R5 = Min(Penentu } \\
\text { Turun, Penyebab Naik, } \\
\text { Pendukung Naik) }\end{array}$ & $\begin{array}{l}\mathrm{z} 5= \\
(\$ R 4 * 25)+25 \\
\$ \mathrm{z} 5=75- \\
(\$ R 3 * 25)\end{array}$ \\
\hline 6 & $\begin{array}{l}\text { R6 = Min(Penentu } \\
\text { Turun, Penyebab Naik, } \\
\text { Pendukung Turun) }\end{array}$ & $\begin{array}{l}\mathrm{z} 6=50- \\
(\$ R 8 * 50)\end{array}$ \\
\hline 7 & $\begin{array}{l}\text { R7 = Min(Penentu } \\
\text { Turun, Penyebab }\end{array}$ & $\begin{array}{l}\mathrm{z7}=50- \\
(\$ R 8 * 50)\end{array}$ \\
\hline
\end{tabular}

\begin{tabular}{|c|c|c|}
\hline & $\begin{array}{l}\text { Turun, Pendukung } \\
\text { Naik) }\end{array}$ & \\
\hline 8 & $\begin{array}{l}\text { R8 = Min(Penentu } \\
\text { Turun, Penyebab } \\
\text { Turun, Pendukung } \\
\text { Turun) }\end{array}$ & $\begin{array}{l}\mathrm{z} 8=50- \\
(\$ R 8 * 50)\end{array}$ \\
\hline
\end{tabular}

\section{HASIL DAN PEMBAHASAN}

\section{Pengolahan Data}

Data yang di inputkan pada sistem yang berupa data induk warga wiskin dan variabelvariabel kemiskinan yang terdiri dari 11 variabel yaitu variabel aspek pangan, aspek sandang, aspek papan, aspek penghasilan, aspek kesehatan, aspek pendidikan, aspek kekayaan, akses air bersih, akses listrik dan jumlah jiwa seperti pada gambar 8 dengan mengacu pada tabel 1. Sistem dibangun menggunakan PHP dengan database MySql..

\section{Input Data Penerima Bantuan}

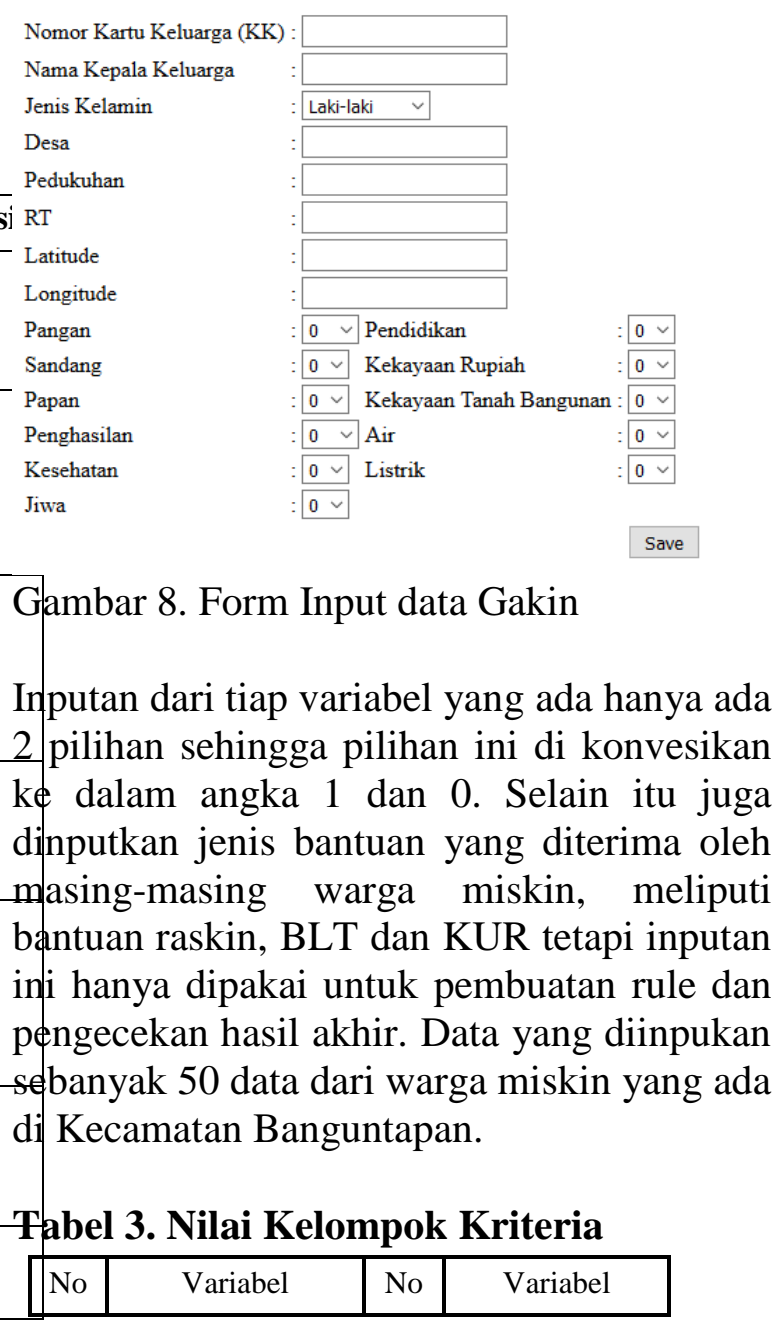




\begin{tabular}{|c|c|c|c|c|c|c|c|}
\hline & $\mathrm{Vt}$ & $\mathrm{Vb}$ & Vp & & $\mathrm{Vt}$ & $\mathrm{Vb}$ & $\mathrm{Vp}$ \\
\hline 1 & 9 & 35 & 10 & 26 & 0 & 35 & 11 \\
\hline 2 & 0 & 35 & 15 & 27 & 0 & 35 & 15 \\
\hline 3 & 0 & 35 & 9 & 28 & 0 & 35 & 15 \\
\hline 4 & 0 & 35 & 17 & 29 & 0 & 35 & 16 \\
\hline 5 & 9 & 35 & 6 & 30 & 0 & 35 & 10 \\
\hline 6 & 9 & 35 & 4 & 31 & 0 & 35 & 20 \\
\hline 7 & 0 & 35 & 11 & 32 & 0 & 35 & 10 \\
\hline 8 & 0 & 35 & 20 & 33 & 0 & 35 & 21 \\
\hline 9 & 0 & 0 & 6 & 34 & 9 & 35 & 15 \\
\hline 10 & 9 & 0 & 15 & 35 & 0 & 35 & 11 \\
\hline 11 & 9 & 0 & 9 & 36 & 0 & 35 & 15 \\
\hline 12 & 9 & 0 & 15 & 37 & 0 & 35 & 15 \\
\hline 13 & 0 & 35 & 10 & 38 & 0 & 0 & 14 \\
\hline 14 & 0 & 35 & 9 & 39 & 9 & 0 & 0 \\
\hline 15 & 9 & 0 & 12 & 40 & 0 & 35 & 20 \\
\hline 16 & 0 & 0 & 9 & 41 & 0 & 0 & 11 \\
\hline 17 & 0 & 35 & 15 & 42 & 0 & 35 & 9 \\
\hline 18 & 0 & 35 & 21 & 43 & 9 & 35 & 9 \\
\hline 19 & 9 & 35 & 4 & 44 & 0 & 35 & 15 \\
\hline 20 & 0 & 0 & 9 & 45 & 0 & 0 & 20 \\
\hline 21 & 0 & 0 & 15 & 46 & 9 & 0 & 16 \\
\hline 22 & 0 & 0 & 19 & 47 & 0 & 0 & 15 \\
\hline 23 & 0 & 0 & 16 & 48 & 9 & 35 & 15 \\
\hline 24 & 0 & 35 & 21 & 49 & 0 & 35 & 0 \\
\hline 25 & 9 & 0 & 9 & 50 & 0 & 35 & 4 \\
\hline
\end{tabular}

Hasil inputan 11 kriteria/variabel dari masingmasing warga miskin dihitung total poin/bobot berdasarkan masing-masing kelompok kriteria yang ditampilkan pada tabel 3. Dari tabel 3 akan dihitung fungsi keanggotaan dari 3 kelompok variabel diatas berdasarkan rumus 1 sampai rumus 9. Hasil dari perhitungan rumus tersebut diperoleh nilai seperti pada tabel 4 .

Tabel 4. Nilai Fungsi Keanggotaan

\begin{tabular}{|c|c|c|c|c|c|c|}
\hline & \multicolumn{5}{|c|}{ NILAI FUNGSI KEANGGOTAAN } \\
\hline No & $\begin{array}{c}\mathrm{Vt} \\
\text { naik }\end{array}$ & $\begin{array}{c}\mathrm{Vt} \\
\text { turun }\end{array}$ & $\begin{array}{c}\mathrm{Vb} \\
\text { naik }\end{array}$ & $\begin{array}{c}\mathrm{Vb} \\
\text { turun }\end{array}$ & $\begin{array}{c}\mathrm{Vp} \\
\text { naik }\end{array}$ & $\begin{array}{c}\mathrm{Vp} \\
\text { turun }\end{array}$ \\
\hline
\end{tabular}

\begin{tabular}{|c|c|c|c|c|c|c|}
\hline 1 & 0.3 & 0.7 & 1 & 0 & 0.286 & 0.7143 \\
\hline 2 & 0 & 1 & 1 & 0 & 0.429 & 0.5714 \\
\hline 3 & 0 & 1 & 1 & 0 & 0.257 & 0.7429 \\
\hline 4 & 0 & 1 & 1 & 0 & 0.486 & 0.5143 \\
\hline 5 & 0.3 & 0.7 & 1 & 0 & 0.171 & 0.8286 \\
\hline 6 & 0.3 & 0.7 & 1 & 0 & 0.114 & 0.8857 \\
\hline 7 & 0 & 1 & 1 & 0 & 0.314 & 0.6857 \\
\hline 8 & 0 & 1 & 1 & 0 & 0.571 & 0.4286 \\
\hline 9 & 0 & 1 & 0 & 1 & 0.171 & 0.8286 \\
\hline 10 & 0.3 & 0.7 & 0 & 1 & 0.429 & 0.5714 \\
\hline 11 & 0.3 & 0.7 & 0 & 1 & 0.257 & 0.7429 \\
\hline 12 & 0.3 & 0.7 & 0 & 1 & 0.429 & 0.5714 \\
\hline 13 & 0 & 1 & 1 & 0 & 0.286 & 0.7143 \\
\hline 14 & 0 & 1 & 1 & 0 & 0.257 & 0.7429 \\
\hline 15 & 0.3 & 0.7 & 0 & 1 & 0.343 & 0.6571 \\
\hline 16 & 0 & 1 & 0 & 1 & 0.257 & 0.7429 \\
\hline 17 & 0 & 1 & 1 & 0 & 0.429 & 0.5714 \\
\hline 18 & 0 & 1 & 1 & 0 & 0.6 & 0.4 \\
\hline 19 & 0.3 & 0.7 & 1 & 0 & 0.114 & 0.8857 \\
\hline 20 & 0 & 1 & 0 & 1 & 0.257 & 0.7429 \\
\hline 21 & 0 & 1 & 0 & 1 & 0.429 & 0.5714 \\
\hline 22 & 0 & 1 & 0 & 1 & 0.543 & 0.4571 \\
\hline 23 & 0 & 1 & 0 & 1 & 0.457 & 0.5429 \\
\hline 24 & 0 & 1 & 1 & 0 & 0.6 & 0.4 \\
\hline 25 & 0.3 & 0.7 & 0 & 1 & 0.257 & 0.7429 \\
\hline 26 & 0 & 1 & 1 & 0 & 0.314 & 0.6857 \\
\hline 27 & 0 & 1 & 1 & 0 & 0.429 & 0.5714 \\
\hline 28 & 0 & 1 & 1 & 0 & 0.429 & 0.5714 \\
\hline 29 & 0 & 1 & 1 & 0 & 0.457 & 0.5429 \\
\hline 30 & 0 & 1 & 1 & 0 & 0.286 & 0.7143 \\
\hline 31 & 0 & 1 & 1 & 0 & 0.571 & 0.4286 \\
\hline 32 & 0 & 1 & 1 & 0 & 0.286 & 0.7143 \\
\hline 33 & 0 & 1 & 1 & 0 & 0.6 & 0.4 \\
\hline 34 & 0.3 & 0.7 & 1 & 0 & 0.429 & 0.5714 \\
\hline 35 & 0 & 1 & 1 & 0 & 0.314 & 0.6857 \\
\hline 36 & 0 & 1 & 1 & 0 & 0.429 & 0.5714 \\
\hline 37 & 0 & 1 & 1 & 0 & 0.429 & 0.5714 \\
\hline 38 & 0 & 1 & 0 & 1 & 0.4 & 0.6 \\
\hline 39 & 0.3 & 0.7 & 0 & 1 & 0 & 1 \\
\hline 40 & 0 & 1 & 1 & 0 & 0.571 & 0.4286 \\
\hline 41 & 0 & 1 & 0 & 1 & 0.314 & 0.6857 \\
\hline
\end{tabular}




\begin{tabular}{|r|r|r|r|r|r|r|}
\hline 42 & 0 & 1 & 1 & 0 & 0.257 & 0.7429 \\
\hline 43 & 0.3 & 0.7 & 1 & 0 & 0.257 & 0.7429 \\
\hline 44 & 0 & 1 & 1 & 0 & 0.429 & 0.5714 \\
\hline 45 & 0 & 1 & 0 & 1 & 0.571 & 0.4286 \\
\hline 46 & 0.3 & 0.7 & 0 & 1 & 0.457 & 0.5429 \\
\hline 47 & 0 & 1 & 0 & 1 & 0.429 & 0.5714 \\
\hline 48 & 0.3 & 0.7 & 1 & 0 & 0.429 & 0.5714 \\
\hline 49 & 0 & 1 & 1 & 0 & 0 & 1 \\
\hline 50 & 0 & 1 & 1 & 0 & 0.114 & 0.8857 \\
\hline
\end{tabular}

Nilai masing-masing fungsi keanggotaan yang ada pada tabel 4 digunakan untuk menghitung nilai implikasi dan agregasi yang disesuaikan dengan aturan yang didefinisikan menjadi 8 rule. Hasil disajikan pada tabel 5 .

Tabel 5. Nilai Aturan Inferensi Tsukamoto

\begin{tabular}{|r|r|r|r|r|r|r|r|r|}
\hline \multirow{2}{*}{ No } & \multicolumn{7}{|c|}{ Nilai Aturan } \\
\cline { 2 - 9 } & $\mathbf{R 1}$ & $\mathbf{R 2}$ & $\mathbf{R 3}$ & $\mathbf{R 4}$ & $\mathbf{R 5}$ & $\mathbf{R 6}$ & $\mathbf{R 7}$ & $\mathbf{R 8}$ \\
\hline 1 & 0.3 & 0.3 & 0.0 & 0.0 & 0.3 & 0.7 & 0.0 & 0.0 \\
\hline 2 & 0.0 & 0.0 & 0.0 & 0.0 & 0.4 & 0.6 & 0.0 & 0.0 \\
\hline 3 & 0.0 & 0.0 & 0.0 & 0.0 & 0.3 & 0.7 & 0.0 & 0.0 \\
\hline 4 & 0.0 & 0.0 & 0.0 & 0.0 & 0.5 & 0.5 & 0.0 & 0.0 \\
\hline 5 & 0.2 & 0.3 & 0.0 & 0.0 & 0.2 & 0.7 & 0.0 & 0.0 \\
\hline 6 & 0.1 & 0.3 & 0.0 & 0.0 & 0.1 & 0.7 & 0.0 & 0.0 \\
\hline 7 & 0.0 & 0.0 & 0.0 & 0.0 & 0.3 & 0.7 & 0.0 & 0.0 \\
\hline 8 & 0.0 & 0.0 & 0.0 & 0.0 & 0.6 & 0.4 & 0.0 & 0.0 \\
\hline 9 & 0.0 & 0.0 & 0.0 & 0.0 & 0.0 & 0.0 & 0.2 & 0.8 \\
\hline 10 & 0.0 & 0.0 & 0.3 & 0.3 & 0.0 & 0.0 & 0.4 & 0.6 \\
\hline 11 & 0.0 & 0.0 & 0.3 & 0.3 & 0.0 & 0.0 & 0.3 & 0.7 \\
\hline 12 & 0.0 & 0.0 & 0.3 & 0.3 & 0.0 & 0.0 & 0.4 & 0.6 \\
\hline 13 & 0.0 & 0.0 & 0.0 & 0.0 & 0.3 & 0.7 & 0.0 & 0.0 \\
\hline 14 & 0.0 & 0.0 & 0.0 & 0.0 & 0.3 & 0.7 & 0.0 & 0.0 \\
\hline 15 & 0.0 & 0.0 & 0.3 & 0.3 & 0.0 & 0.0 & 0.3 & 0.7 \\
\hline 16 & 0.0 & 0.0 & 0.0 & 0.0 & 0.0 & 0.0 & 0.3 & 0.7 \\
\hline 17 & 0.0 & 0.0 & 0.0 & 0.0 & 0.4 & 0.6 & 0.0 & 0.0 \\
\hline 18 & 0.0 & 0.0 & 0.0 & 0.0 & 0.6 & 0.4 & 0.0 & 0.0 \\
\hline 19 & 0.1 & 0.3 & 0.0 & 0.0 & 0.1 & 0.7 & 0.0 & 0.0 \\
\hline 20 & 0.0 & 0.0 & 0.0 & 0.0 & 0.0 & 0.0 & 0.3 & 0.7 \\
\hline 21 & 0.0 & 0.0 & 0.0 & 0.0 & 0.0 & 0.0 & 0.4 & 0.6 \\
\hline 22 & 0.0 & 0.0 & 0.0 & 0.0 & 0.0 & 0.0 & 0.5 & 0.5 \\
\hline
\end{tabular}

\begin{tabular}{|l|l|l|l|l|l|l|l|l|}
23 & 0.0 & 0.0 & 0.0 & 0.0 & 0.0 & 0.0 & 0.5 & 0.5 \\
\hline 24 & 0.0 & 0.0 & 0.0 & 0.0 & 0.6 & 0.4 & 0.0 & 0.0 \\
\hline 25 & 0.0 & 0.0 & 0.3 & 0.3 & 0.0 & 0.0 & 0.3 & 0.7 \\
\hline 26 & 0.0 & 0.0 & 0.0 & 0.0 & 0.3 & 0.7 & 0.0 & 0.0 \\
\hline 27 & 0.0 & 0.0 & 0.0 & 0.0 & 0.4 & 0.6 & 0.0 & 0.0 \\
\hline 28 & 0.0 & 0.0 & 0.0 & 0.0 & 0.4 & 0.6 & 0.0 & 0.0 \\
\hline 29 & 0.0 & 0.0 & 0.0 & 0.0 & 0.5 & 0.5 & 0.0 & 0.0 \\
\hline 30 & 0.0 & 0.0 & 0.0 & 0.0 & 0.3 & 0.7 & 0.0 & 0.0 \\
\hline 31 & 0.0 & 0.0 & 0.0 & 0.0 & 0.6 & 0.4 & 0.0 & 0.0 \\
\hline 32 & 0.0 & 0.0 & 0.0 & 0.0 & 0.3 & 0.7 & 0.0 & 0.0 \\
\hline 33 & 0.0 & 0.0 & 0.0 & 0.0 & 0.6 & 0.4 & 0.0 & 0.0 \\
\hline 34 & 0.3 & 0.3 & 0.0 & 0.0 & 0.4 & 0.6 & 0.0 & 0.0 \\
\hline 35 & 0.0 & 0.0 & 0.0 & 0.0 & 0.3 & 0.7 & 0.0 & 0.0 \\
\hline 36 & 0.0 & 0.0 & 0.0 & 0.0 & 0.4 & 0.6 & 0.0 & 0.0 \\
\hline 37 & 0.0 & 0.0 & 0.0 & 0.0 & 0.4 & 0.6 & 0.0 & 0.0 \\
\hline 38 & 0.0 & 0.0 & 0.0 & 0.0 & 0.0 & 0.0 & 0.4 & 0.6 \\
\hline 39 & 0.0 & 0.0 & 0.0 & 0.3 & 0.0 & 0.0 & 0.0 & 0.7 \\
\hline 40 & 0.0 & 0.0 & 0.0 & 0.0 & 0.6 & 0.4 & 0.0 & 0.0 \\
\hline 41 & 0.0 & 0.0 & 0.0 & 0.0 & 0.0 & 0.0 & 0.3 & 0.7 \\
\hline 42 & 0.0 & 0.0 & 0.0 & 0.0 & 0.3 & 0.7 & 0.0 & 0.0 \\
\hline 43 & 0.3 & 0.3 & 0.0 & 0.0 & 0.3 & 0.7 & 0.0 & 0.0 \\
\hline 44 & 0.0 & 0.0 & 0.0 & 0.0 & 0.4 & 0.6 & 0.0 & 0.0 \\
\hline 45 & 0.0 & 0.0 & 0.0 & 0.0 & 0.0 & 0.0 & 0.6 & 0.4 \\
\hline 46 & 0.0 & 0.0 & 0.3 & 0.3 & 0.0 & 0.0 & 0.5 & 0.5 \\
\hline 47 & 0.0 & 0.0 & 0.0 & 0.0 & 0.0 & 0.0 & 0.4 & 0.6 \\
\hline 48 & 0.3 & 0.3 & 0.0 & 0.0 & 0.4 & 0.6 & 0.0 & 0.0 \\
\hline 49 & 0.0 & 0.0 & 0.0 & 0.0 & 0.0 & 1.0 & 0.0 & 0.0 \\
\hline 50 & 0.0 & 0.0 & 0.0 & 0.0 & 0.1 & 0.9 & 0.0 & 0.0 \\
\hline
\end{tabular}

Setelah diperoleh nilai Implikasi aturan dan nilai agregasinya maka tahapan berikutnya adalah menghitung nilai defuzzifikasinya untuk mendapat nilai yang sebenarnya dari masing-masing warga miskin. Hasil defuzzifikasinya ini akan dikonversikan ke dalam tiga kategori bantuan yang ada yaitu BLT, Raskin dan KUR. Hasil tersebut dapat dllihat pada tabel 6 .

Tabel 6. Perbandingan Hasil Sistem

\begin{tabular}{|c|c|c|c|c|c|c|c|}
\hline $\mathbf{N}$ & $\mathbf{Z}$ & $\begin{array}{c}\text { Data } \\
\text { Asli }\end{array}$ & $\begin{array}{c}\text { Hasil } \\
\text { Siste } \\
\mathbf{m}\end{array}$ & $\begin{array}{c}\mathbf{N} \\
\mathbf{0}\end{array}$ & $\mathbf{Z}$ & $\begin{array}{c}\text { Data } \\
\text { Asli }\end{array}$ & $\begin{array}{c}\text { Hasil } \\
\text { Siste } \\
\mathbf{m}\end{array}$ \\
\hline
\end{tabular}




\begin{tabular}{|c|c|c|c|c|c|c|c|}
\hline 1 & $\begin{array}{r}43 . \\
6\end{array}$ & $\begin{array}{l}\text { raski } \\
\mathrm{n}\end{array}$ & BLT & 26 & $\begin{array}{r}21 . \\
1\end{array}$ & $\begin{array}{l}\text { raski } \\
\mathrm{n}\end{array}$ & Raskin \\
\hline 2 & $\begin{array}{r}39 . \\
8\end{array}$ & blt & BLT & 27 & $\begin{array}{r}39 . \\
8\end{array}$ & blt & BLT \\
\hline 3 & $\begin{array}{r}17 . \\
6\end{array}$ & $\begin{array}{l}\text { raski } \\
\mathrm{n}\end{array}$ & Raskin & 28 & $\begin{array}{r}39 . \\
8\end{array}$ & $\begin{array}{l}\text { raski } \\
\mathrm{n}\end{array}$ & BLT \\
\hline 4 & 43 & blt & BLT & 29 & $\begin{array}{r}41 . \\
5\end{array}$ & blt & BLT \\
\hline 5 & $\begin{array}{r}39 . \\
4\end{array}$ & blt & BLT & 30 & $\begin{array}{r}19 . \\
4\end{array}$ & blt & Raskin \\
\hline 6 & $\begin{array}{r}24 . \\
3\end{array}$ & $\begin{array}{l}\text { raski } \\
n\end{array}$ & Raskin & 31 & $\begin{array}{r}46 . \\
9\end{array}$ & blt & Kur \\
\hline 7 & $\begin{array}{r}21 . \\
1\end{array}$ & kur & Raskin & 32 & $\begin{array}{r}19 . \\
4\end{array}$ & $\begin{array}{l}\text { raski } \\
n\end{array}$ & Raskin \\
\hline 8 & $\begin{array}{r}46 . \\
9\end{array}$ & $\begin{array}{l}\text { raski } \\
n\end{array}$ & Kur & 33 & 48 & $\begin{array}{l}\text { raski } \\
n\end{array}$ & Kur \\
\hline 9 & $\begin{array}{r}14 . \\
2\end{array}$ & $\begin{array}{l}\text { raski } \\
n\end{array}$ & Raskin & 34 & $\begin{array}{r}49 . \\
7\end{array}$ & blt & Kur \\
\hline 10 & 28 & blt & Raskin & 35 & $\begin{array}{r}21 . \\
1\end{array}$ & $\begin{array}{l}\text { raski } \\
n\end{array}$ & Raskin \\
\hline 11 & $\begin{array}{r}25 . \\
5\end{array}$ & $\begin{array}{l}\text { raski } \\
n\end{array}$ & Raskin & 36 & $\begin{array}{r}39 . \\
8\end{array}$ & kur & BLT \\
\hline 12 & 28 & $\begin{array}{l}\text { raski } \\
n\end{array}$ & Raskin & 37 & $\begin{array}{r}39 . \\
8\end{array}$ & kur & BLT \\
\hline 13 & $\begin{array}{r}19 . \\
4\end{array}$ & blt & Raskin & 38 & 24 & $\begin{array}{l}\text { raski } \\
n\end{array}$ & Raskin \\
\hline 14 & $\begin{array}{r}17 . \\
6\end{array}$ & $\begin{array}{l}\text { raski } \\
n\end{array}$ & Raskin & 39 & 21 & blt & Raskin \\
\hline 15 & $\begin{array}{r}26 . \\
7\end{array}$ & $\begin{array}{l}\text { raski } \\
n\end{array}$ & Raskin & 40 & $\begin{array}{r}46 . \\
9\end{array}$ & $\begin{array}{l}\text { raski } \\
n\end{array}$ & Kur \\
\hline 16 & $\begin{array}{r}19 . \\
1\end{array}$ & $\begin{array}{l}\text { raski } \\
n\end{array}$ & Raskin & 41 & $\begin{array}{r}21 . \\
6\end{array}$ & blt & Raskin \\
\hline 17 & $\begin{array}{r}39 . \\
8\end{array}$ & $\begin{array}{l}\text { raski } \\
n\end{array}$ & BLT & 42 & $\begin{array}{r}17 . \\
6\end{array}$ & blt & Raskin \\
\hline 18 & 48 & blt & Kur & 43 & $\begin{array}{r}42 . \\
6\end{array}$ & $\begin{array}{l}\text { raski } \\
n\end{array}$ & BLT \\
\hline 19 & $\begin{array}{r}24 . \\
3\end{array}$ & blt & Raskin & 44 & $\begin{array}{r}39 . \\
8\end{array}$ & blt & BLT \\
\hline 20 & $\begin{array}{r}19 . \\
1\end{array}$ & $\begin{array}{l}\text { raski } \\
n\end{array}$ & Raskin & 45 & $\begin{array}{r}24 . \\
5\end{array}$ & blt & Raskin \\
\hline 21 & $\begin{array}{r}24 . \\
5\end{array}$ & $\begin{array}{l}\text { raski } \\
n\end{array}$ & Raskin & 46 & $\begin{array}{r}28 . \\
2\end{array}$ & blt & Raskin \\
\hline 22 & $\begin{array}{r}24 . \\
8\end{array}$ & $\begin{array}{l}\text { raski } \\
n\end{array}$ & Raskin & 47 & $\begin{array}{r}24 . \\
5\end{array}$ & $\begin{array}{l}\text { raski } \\
n\end{array}$ & Raskin \\
\hline 23 & $\begin{array}{r}24 . \\
8\end{array}$ & kur & Raskin & 48 & $\begin{array}{r}49 . \\
7\end{array}$ & kur & Kur \\
\hline 24 & 48 & kur & Kur & 49 & 0 & $\begin{array}{l}\text { raski } \\
\mathrm{n}\end{array}$ & Raskin \\
\hline 25 & $\begin{array}{r}25 . \\
5\end{array}$ & $\begin{array}{l}\text { raski } \\
n\end{array}$ & Raskin & 50 & $\begin{array}{r}8.2 \\
4\end{array}$ & blt & Raskin \\
\hline
\end{tabular}

Dari tabel 5 terlihat bahwa hasil rekomendasi atau identifikasi bantuan menggunakan metode Tsukamoto dari 50 data yang digunakan terdapat 26 data yang sesuai dengan data asli. Hasil ini menunjukkan bahwa metode tsukamoto memberikan hasil identifikasi sebesar $52 \%$.

\section{KESIMPULAN}

Dari hasil penjelasan yang ada pada bab sebelumnya maka dapat diambil kesimpulan mengenai hasil penelitian antara lain : a. Metode Fuzzy Tsukamoto dapat dijadikan alternatif untuk melakukan rekomendasi pemberian bantuan kemiskinan bagi warga miskin.

b. Penentuan aturan (rule) sangat mempengaruhi hasil akhir atau proses defuzzifikasi Tsukamoto.

c. Fungsi keanggotaan yang di gunakan pada penelitian ini hanya berdasarkan 2 variabel yaitu fungsi keanggotaan jenis bantuan dan kelompok kriteria kemiskinan.

d. Ketepatan identifikasi metode tsukamoto pada penelitian ini hanya $52 \%$. 


\section{DAFTAR PUSTAKA}

BKKBN. 2006. Kependudukan dan Pembangunan. Diakses Februari 14, 2013. http://www.bkkbn.go.id/news-detail.php?nid790.

Cahyat, A. 2004. "Bagaimana Kemiskinan Diukur? Beberapa Model Penghitungan Kemiskinan di Indonesia." Center for International Forestry Research (CIFOR) 1-8.

Klir, G. J, dan Y. Bo. 1995. Fuzzy Set and Fuzzy Logic : Theory and Applications. New Jersey: Prentice Hall International.

Kusumadewi, Sri. 2004. Aplikasi Logika Fuzzy untuk Pendukung Keputusan. Yogyakarta: Graha Ilmu.

Peraturan Bupati Bantul. 2007. Nomor 21A

Pernia, Ernesto M, dan Quibra G. M. 1999. Poverty in Developing Countries, Handbook of Regional and Urban Economics Vol 3. Amsterdam: Elseiver.

Rohayani, Hetty. 2015. "Fuzzy Inference System Dengan Metode Tsukamoto Sebagai Penunjang Keputusan Produksi (Studi Kasus : PT Talkindo Selaksa Anugrah).” Jurnal Sistem Informasi (JSI).

Royat, Sujana. 2015. Kebijakan Pemerintah dalam Penanggulangan Kemiskinan. Jakarta.

Sholihin, Miftahus, Fuad Nurul, dan Khamiliyah Nurul . 2013. "Sistem pendukung keputusan penentuan warga penerima Jamkesmas dengan metode Fuzzy Tsukamoto.” Jurnal Teknika.

Singhala, P, D N Shah, dan B Patel. 2014. "Temperature Control using Fuzzy Logic." International Journal of Instrumentation and Control Systems (IJICS) 1-10.

Sri , Harijati Hatmadji. 2004. Empowerment of Indonesian Women: Family, Reproductive Health, Employment and Migration. Depok, FEUI.

Sugianti. 2016. "Menentukan Penerima Kps Menggunakan Fuzzy Inference System Metode Tsukamoto." Jurnal Ilmiah Multitek Indonesia.

TNP2K. 2012. Panduan Pemantauan Program Penanggulangan Kemiskinan: Buku Pegangan TKPK Daerah. Jakarta.

TNP2K. 2011. Program Bantuan Sosial Dan Penanggulangan Kemiskinan. Jakarta.

Wijayaningrum, , Vivi Nur, dan Wayan Firdaus Mahmudy. t.thn. "Penentuan Prioritas Rumah Tangga Miskin Menggunakan Fuzzy Tsukamoto.” Prosiding Seminar Nasional Teknologi Informasi dan Komunikasi 2016. Yogyakarta. 2016.

\section{BIOGRAFI}

Nama Penulis : Sri Redjeki,S.Si,M.Kom, Lahir di Surabaya, 21 April 1974, Menyelesaikan Magister Ilmu Komputer tahun 2005 di Universitas Gadjah Mada. Staf Pengajar di STMIK AKAKOM Yogyakarta. Bidang Ilmu : Data Mining, Kecerdasan Buatan dan Statistika Terapan. 